\title{
Indoor Fungal Treatment by Using Potassium Sorbate as Bio-Resistance Coating for Different Plasterboard Wall Finishings
}

\author{
U.K. Parjo ${ }^{1 *}$, N. M. Sunar ${ }^{1}$, A.M. Leman ${ }^{1}$, N.I.A. Ideris ${ }^{2}$, P.Gani ${ }^{2}$, \\ Q. Emparan², C.M. Er ${ }^{2}$
}

${ }^{1}$ Department of Chemical Engineering Technology, Faculty of Engineering Technology (FTK), Universiti Tun Hussein Onn Malaysia (UTHM), 86400, Parit Raja, Batu Pahat, Johor, Malaysia
${ }^{2}$ Department of Water and Environmental Engineering, Faculty of Civil and Environmental Engineering (FKAAS), University Tun Hussein Onn Malaysia (UTHM) 86400, Parit Raja, Batu Pahat, Johor, Malaysia
1*umi5506@yahoo.com, ${ }^{1}$ shuhaila@uthm.edu.my, ${ }^{1}$ mutalib@uthm.edu.my, ${ }^{2}$ izaitulakm@gmail.com, 2parancgat@yahoo.com, 2quinston89@gmail.com, 2erchinming@hotmail.com,

Keywords: Indoor air quality, potassium sorbate, plasterboard, wall finishing

\begin{abstract}
Good indoor environmental quality (IEQ) is desired for a healthy indoor environment. Microbial growth in indoor environments that contributes to poor indoor environmental quality can cause various health problems. The aim of this study is to enumerate the indoor fungal growth in complaint area and determine the effectiveness of potassium sorbate in bio-resistance coating against fungi by using different wall on plasterboard.Plasterboard wall was used as a substrate to see the influence of different common wall finishings used such as paints and wallpapers on fungal growth. Potassium sorbate was tested against fungi isolated from affected room M146, FKAAS building. The total fungal count in the affected room was $806 \mathrm{cfu} / \mathrm{m}^{3}$. ASTM D5590-00 standard was used to evaluate fungal growth and determine if potassium sorbate was effective in inhibiting the amount of fungal growth in four types of plasterboard wall finishings used on plasterboard walls. As a result, the percentage reduction in growth between control and treatment samples were $10 \%$ thin wallpaper, $15 \%$ acrylic paint, $25 \%$ glycerol-based paint and $60 \%$ on thick wallpaper.
\end{abstract}

\subsection{Introduction}

Indoor Environmental Quality (IEQ) in buildings was assessed from the possibility of inmates acceptance in the aspects of indoor air quality, thermal comfort, noise level and level of illumination [1]. Concerns about issues of indoor air quality caused by mold growth has increased dramatically nowadays in residential and commercials structures [2]. It is commonly known that molds, mildews, and other fungi favor growth in humid environments. High humidity and moisture are typically associated with the outdoors, where fungal growth can produce unsightly appearance on building facades. Indoor environment also often have adequate humidity and moisture to support fungal growth [3]. Fungal growth in indoor air is being proposed as a cause of adverse health effects. Exposure to molds has been reported to cause several types of human health problems, especially itching, infections, allergies, and toxic effects, and it has been suggested that toxigenic fungi can cause additional adverse health effects [4]. Any number of reasons may be responsible for mold infestation in existing structures, such as the original design, poor construction practices, poor site drainage, leaking roofs or pipes, insufficient insulation, and improper ventilation [2].The advantageous to formulate paints with antimicrobial substances that are stable across a range of effectiveness and show the $\mathrm{pH}$ at a relatively low concentration [6]. Thus, the objective of this study is to enumerate the indoor fungal growth in complaint area and determine the effectiveness of potassium sorbate in bio-resistance coating against fungi by using different wall finishings on plasterboard. 


\subsection{Materials and methods}

\subsection{Indoor air quality (IAQ) physical parameters reading}

The indoor air quality parameters were taken at Faculty of Civil and Environmental Engineering (FKAAS) in UTHM campus, which is a new and occupied building that have been identified as having microbial growth in indoor environment. Four important specific physical parameters were taken which were temperature, relative humidity, air movement and carbon dioxide.In this study, samples of fungi were collected. Fungi will be selected and isolated using the established available method and data based on previous studies.

\subsection{Airborne fungi and bacteria measurement}

Airborne fungi and bacteria samples were collected using the BioStage ${ }^{\circledR}$ single-stage viable cascade impactor attached to a SKC QuickTake ${ }^{\circledR} 30$ Sample Pump with Malt Extract Agar plates (MEA) at a flow rate of $28.3 \mathrm{~L} / \mathrm{min}$ as per requirement of National Institute of Occupational Safety and Health (NIOSH) by NIOSH Manual Analytical Standard Method (NMAM 0800). The sampling pump with representative sampler in line was calibrated before each use using a rotatmeter and the sampling height was 1.2 to $1.5 \mathrm{~m}$ and set at the center of the room for 5 minutes sampling. Air was drawn through the impactor where particles were impacted onto an agar collection medium. The plates with MEA were incubated at $25^{\circ} \mathrm{C}$ for 5 days for fungal growth.

\subsection{Laboratory work}

Two tests were conducted in the laboratory, namely cultivation, spore suspension and coatings bio-resistance test. All tests were conducted at Microbiology Laboratory of Faculty of Engineering Technology (FTK), University of TunHussein Onn Malaysia.

\subsubsection{Sampling of fungi}

Malt Extract Agar (MEA) was used as fungal culture medium. All bioaerosol samplings were conducted in triplicate. After samplings, bacterial plates were incubated in an inverted position at $35^{\circ} \mathrm{C}$ for two days and fungal plates at $25{ }^{\circ} \mathrm{C}$ for three to five days[7]. After the desired duration of incubation, the colonies formed were counted.

\subsubsection{Fungal growth and enumeration}

Samples were assessed in the laboratory for enumeration and identification of viable fungi and bacteria. Colony-forming units per cubic meter $\left(\mathrm{CFU} / \mathrm{m}^{3}\right)$ was used to demonstrate the levels of fungi and bacteria in the air. Average concentrations of these samples were used to present the microbial levels for each sampling time. Fungi were identified microscopically to determine its genus and bacterial identification were performed via Gram stain. The total number of colonies, total fungal and total bacterial number were counted and calculated in terms of colony-forming units per cubic metre of air $\left(\mathrm{CFU} / \mathrm{m}^{3}\right)$.

\subsubsection{Isolation and cultivation of spore}

Isolation from biological samples is typically preceded by a heat treatment step to kill all vegetative microorganisms while cultivation of suspension spore is the aseptic transfer of microorganisms from a culture to fresh medium. Streak-plate method is commonly used to obtain isolated colonies. From the subculture, the spore suspension was prepared in solid culture medium during 25 to 30 days at the temperature $25^{\circ} \mathrm{C} \pm 2{ }^{\circ} \mathrm{C}$ and the concentration adjusted to $0.3-0.5 \times 10^{6}$ spores $/ \mathrm{mL}$ by using "Neubauer chamber" [5].

\subsubsection{Coatings bio-resistance test}

The plasterboards were cut into samples of size $50 \mathrm{mmx} 50 \mathrm{~mm}$ was washed in alcohol and dried. Four types of wall finishing such as acrylic paint, glycerol based paint, thick and thin wallpaper were covered onto supports. All samples were left to dry 24 to 48 hours. Before placed in 
petri dish, all samples were irradiated with UV lamp for 40 minutes to avoid any contamination. Then a $50 \mu 1$ of spore suspension was putted on plasterboard surface and temperature was setting $37^{\circ} \mathrm{C}$ in incubator. Each test carried out in triplicate at the same period with observation until 15 days. According ASTM D5590-00 standard specification, the rate of fungal growth on wall finishings of plasterboard was evaluated.

\subsection{Results and Discussion}

\subsection{The coatings bio-resistant test}

The capability of the biocide to prevent fungal growth in indoor buildings was indicated by the growth of fungi according to ASTM D5590-00 standard scale. Figure 1 and Figure 2 show the results observed within 15 days for samples on different types of wall finishings used according to the ASTM D5590-00 standard scale.

Figure 1 shows the bar graph for overall observation results in terms of percentage of growth for control samples within 15 days on differents types of wall finishings used and Figure 2 shows the bar graph for overall observation results in terms of percentage of growth for biocide treatment samples within 15 days on differents types of wall finishings used according to the ASTMD5590-00 standard scale rating.Both overall graphs in Figure 1 and Figure 2 illustrate the differences in percentage of fungal growth by comparing fungal growth without treatment (control samples) with the biocide treatment samples. The graph for percentage reduction of fungal growth is illustrated in Figure 3.

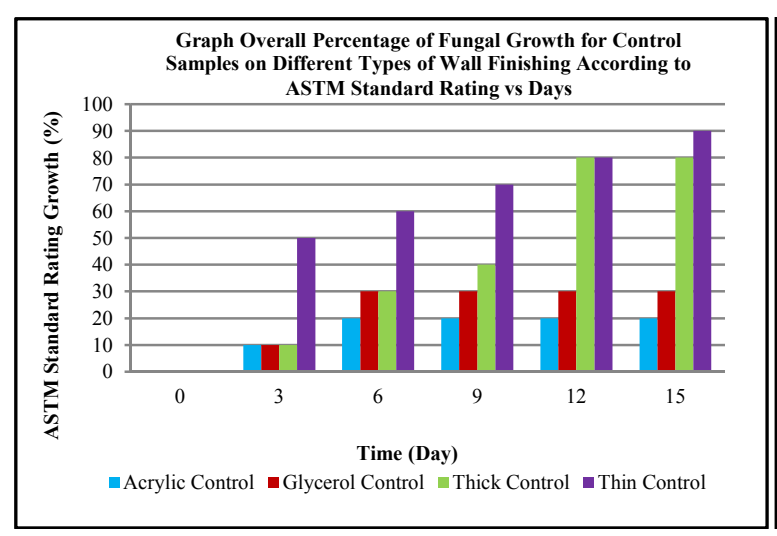

Figure 1: Observations on different types of wall finishings for control samples

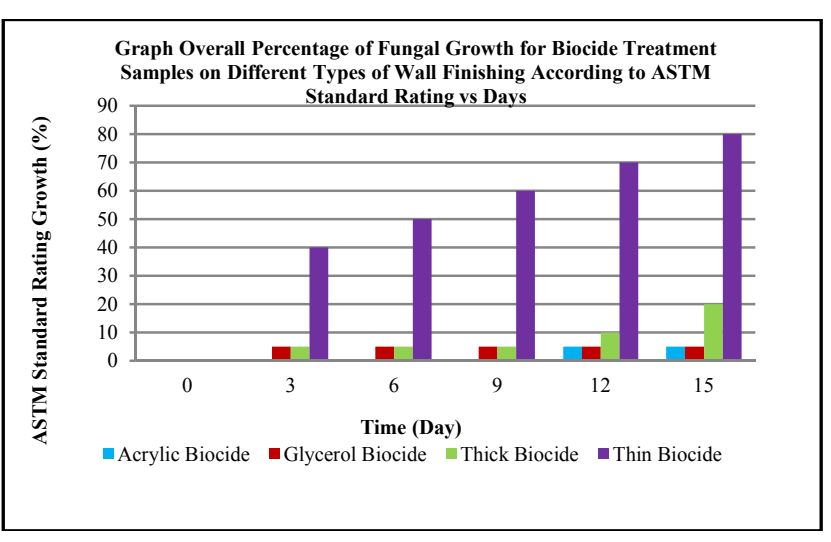

Figure 2: Observations on different types of wall finishings for treatment samples

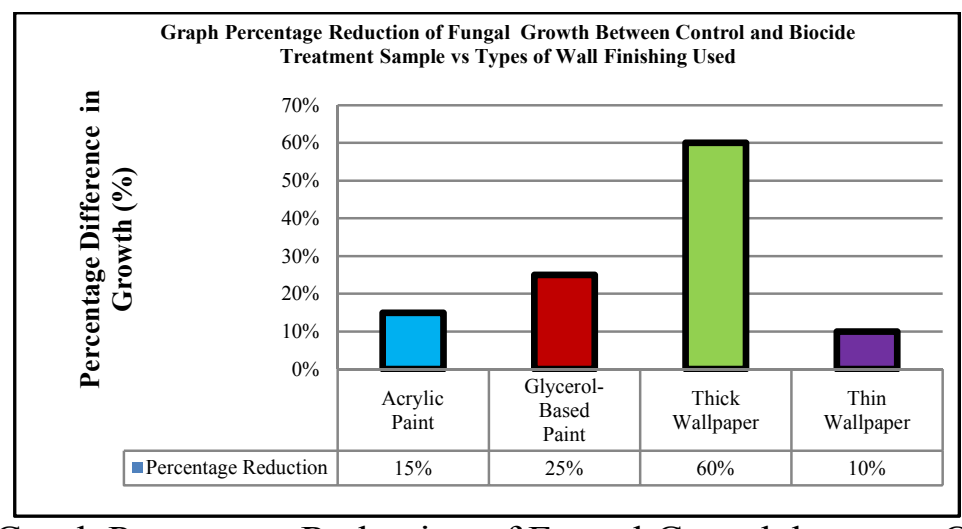

Figure 3: Graph Percentage Reduction of Fungal Growth between Control and Biocide Treatment Samples for Different Types of Wall Finishings Used 
From Figure 3, acrylic paint shows $15 \%$ of fungal growth reduction. The growth of fungi was still present on acrylic paint with biocide added because of the disadvantages of acrylic paint itself. This problem occurs primarily when the paint is applied at low temperature and high humidity that contribute to fungal growth. However in some application, the paint can tolerate to moisture due to high polymer molecular weight[14].For Glycerol-based paint, the reduction of fungal growth was $25 \%$ by using selected biocide. Even though glycerol can give flexibility and toughness in paints and coatings surfaces, it can retain moisture that leads to fungal growth [15]. Thick wallpaper gave the highest percentage reduction of fungal growth as compared to the other three types of wall finishings used which was $60 \%$. This highest decrease of growth was because of the characteristic of the thick wallpaper itself that has less fungicidal effect [16]. The lowest percentage reduction value is seen in thin wallpaper which was only $10 \%$. This lowest decrease of fungal growth was because it has more fungicidal effect compared to the other three types of finishings used[17]. Thin wallpaper has more nutrients to support fungal growth.

\subsection{Conclusions}

From the study it can be concluded that potassium sorbate was effective in order to decrease the amount of fungal growth from FKAAS affected room M146. All the indoor air parameters measured were complied with standard guidelines except for relative humidity. The results showed that the total fungal count in the affected room was enumerated to $806 \mathrm{cfu} / \mathrm{m}^{3}$. Although the amount was still in the standard guideline limit, but the presence of fungiin the room can cause uncomfortable conditions and lead to health effects. According to the ASTM D5590-00 standard scale rating the fungal growth can be evaluated within 15 days by naked eye observation. The results obtained were tabulated to compare the growth in different types of wall finishings and materials used. The results indicated that the treatment was effective to inhibit $15 \%$ of fungal growth on acrylic paint, $25 \%$ on glycerol-based paint, $60 \%$ in thick wall paper and $10 \%$ on thin wall paper for plasterboard.

\section{ACKNOWLEDGEMENTS}

The authors wish to thank UniversitiTun Hussein Onn Malaysia for its full support in the effort to conduct this research study. The authors would also like to acknowledge all participants involved in this research.

\section{REFERENCES}

[1] Wong, L.T., Mui, K.W. \&Hui, P.S. (2008). A Multivariate-Logistic Model for Acceptance of Indoor Environmental Quality (IEQ) in Offices.Elsevier,Science Direct, Building and environment, 1-6.

[2] Clausen, A.C. \& Yang, V.W. (2003). Mold Inhibition on Unseasoned Southern Pine. Brisbane, Australia: USDA Forest Service Forest Products Laboratory One Gifford Pinchot Drive Madison, Wisconsin 53726 USA.

[3] Gorton, S.J. \& Rowlett, T.X. (2007). Building Material Surface Treatment Biocide, And Method For Treatment Of Building Material Surface.U.S. Patent No. US2007/0110780 A1.

[4] Shelton, B.G., Kirkland, K.H., Flanders, W.D. \& Morris, G.K. (2002). Profiles of Airborne Fungi in Buildings and Outdoor Environments in the United States.Applied And Environmental Microbiology, 1743-1753.

[5] Bellotti, N., Salvatore, L., Deyá, C., Del Panno, M. T., Del Amo, B., \&Romagnoli, R. (2013). The aplication of bioactive compounds from the food industry to control mould growth in indoor waterborne coatings. Colloids and Surfaces B: Biointerfaces.

[6] Hochmannovaa, L. \&Vytrasova, J. (2010). PhotocatalyticAnd Antimicrobial Effects of Interior paints. Elsevier,Progress in Organic Coatings , 1-5. 
[7] Rajasekar, A. and Balasubramanian, R. (2011). "Assessment of airborne bacteria and fungi in food courts. "Building and Environment46(10): 2081-2087.

[8] Kamaludin, N.S. (2013). The Phycoremediation of Botryococcussp.To Treat Greywater. UniversitiTun Hussein Onn Malaysia: Degree's Project Report

[9] DOSH (2010). Industry Code of Practice on Indoor Air Quality 2010, Ministry of Human Resources. Department of Occupational Safety and Health, Malaysia.

[10] OHS. (2012). Indoor Air Quality (IAQ). Retrieved October 06, 2013, from Occupational Health and Safety Bulletin, Alberta: www.employment.alberta.ca/ohs-legislation

[11] Zadražil, F. (1975). Influence of CO 2 concentration on the mycelium growth of three Pleurotus species. Applied Microbiology and Biotechnology, 1(4), 327-335.

[12] Kanaani, H., Hargreaves, M., Ristovski, Z., \&Morawska, L. (2009). Fungal spore fragmentation as a function of airflow rates and fungal generation methods. Atmospheric Environment, 43(24), 3725-3735.

[13] EPA. (2010, September).A Brief Guide To Mold, Moisture, And Your Home. Retrieved December 03, 2013, from Environmental Protection Agency, United States: www.epa.gov/iaq

[14] Mariz, I.D.F.A., Millichamp, I.S., Cal, J.C.D.L. \&Leiza, J.R. (2010). High Performance Water-Borne Paints With High Volume Solids Based on Bimodal Latexes. Elsevier, ScienceDirect, Progress in Organic Coatings , 225-233

[15] Pagliaro, M. \& Rossi, M. (2008). The Future of Glycerol: New Uses of a Versatile Raw Material. Retrieved December 10, 2013, from Springer, Organic Chemistry, Future of Glycerol:http://www.springer.com/chemistry/organic+chemistry/book/978-0-85404-124-4

[16] Vacher, S., Hernandez, C., Bartschi, C. \&Poussereau, N. (2010). Impact of Paint And WallPaper on Mould Growth on Plasterboards And Aluminum. Elsevier, Building and Environment , 916-921.

[17] WHO. (2009). WHO Guidelines For Indoor Air Quality: Dampness And Mould. Retrieved May 27, 2013, from World health Organization, Europe: www.euro.who.int 